\title{
Effectiveness of Chemo- and Thermotherapeutic Treatments on Pepino mosaic virus in Tomato Seed
}

\author{
Kai-Shu Ling, United States Department of Agriculture-Agricultural Research Service, U.S. Vegetable Laboratory, \\ Charleston, SC 29414
}

\begin{abstract}
Ling, K.-S. 2010. Effectiveness of chemo- and thermotherapeutic treatments on Pepino mosaic virus in tomato seed. Plant Dis. 94:325-328.

Pepino mosaic virus (PepMV) is a seedborne virus of importance in greenhouse tomato. The ease of mechanical transmission of PepMV from contaminated tomato seed to seedlings makes commercial tomato seed a potential source of initial virus inoculum. The objective of this study was to evaluate the effectiveness of chemo- and thermotherapeutic treatments on PepMV using seed from a commercial hybrid tomato seed lot. The effect of various seed treatments was evaluated through bioassay with mechanical inoculation of the treated seed extract on indicator plants (Nicotiana benthamiana). Three commonly used seed-treatment chemicals and two thermotreatment methods were evaluated. The most effective chemical was the commercial bleach solution ( 0.5 and $1.0 \%$ sodium hypochlorite), followed by trisodium phosphate. On the other hand, hydrochloric acid treatments were not effective. Under the stated chemotherapeutic treatment conditions, the rate of seed germination was not significantly affected. With thermotherapeutic treatments, although hot water soaking for $2 \mathrm{~h}$ at $55^{\circ} \mathrm{C}$ deactivated virus infectivity, it also resulted in a detrimental effect on seed germination. However, treatment with dry-heat baking ( 72 or $80^{\circ} \mathrm{C}$ for 48 to $72 \mathrm{~h}$ ) was effective in reducing PepMV infection with minimum impact on seed germination.
\end{abstract}

In the 10 years since its first report to infect tomato (Solanum lycopersicum L.) in 1999 (19), Pepino mosaic virus (PepMV), a Potexvirus sp., has become an important virus infecting greenhouse tomato plants in Europe (2,5,6,13-16), North America $(3,10,12)$, South America $(8,18)$, and Asia (20). Although commercial tomato seed has long been suspected to be a source of initial virus inoculum, earlier reports on natural seed transmission of PepMV in tomato were in conflict. Salomon and Roggero (17) showed no seed transmission of PepMV in tomato. Cordoba-Selles et al. (1) claimed to have observed a low rate $(<2 \%)$ of seed transmission. An even lower rate of seed transmission $(0.026 \%)$ was recently reported in a larger number of grow-out seedlings (approximately 90,000) tested in multiple laboratories in Europe (4). The mechanism of PepMV transmis-

Corresponding author: K.-S. Ling

E-mail: kai.ling@ars.usda.gov

Mention of trade names or commercial products in this article is solely for the purpose of providing specific information and does not imply recommendation or endorsement by the United States Department of Agriculture.

Accepted for publication 4 November 2009.

doi:10.1094/PDIS-94-3-0325

This article is in the public domain and not copyrightable. It may be freely reprinted with customary crediting of the source. The American Phytopathological Society, 2010 sion from tomato seed to seedlings has only recently been elucidated (9). Although no direct seed transmission of the virus in over 10,000 grow-out seedlings was observed, that study showed that localization of PepMV was on the seed coat but not on the embryo, and the ease of mechanical transmission of PepMV from contaminated tomato seed to seedling was responsible for initiating virus infection (9). In general, Potexvirus spp. are not considered to be seed transmitted. Thus, authors in the recent report (4) speculated that the extremely low rate of seed transmission $(0.026 \%)$ as observed in nearly 90,000 grow-out seedlings was likely due to the contact between the germinating seedlings and the virus-contaminated seed coat. The notion that PepMV is a seedborne but not seed-transmitted virus implies that seedling grow-out tests may not reflect the actual virus status of the seed. Bioassay by inoculating the processed seed extract on indicator plants (Nicotiana benthamiana) is more appropriate in assessing the presence of infectious virus particles remaining on the treated tomato seed. In fact, such a virus assay is also recommended by the International Seed Health Initiative for Vegetables (ISHI_Veg). In seed treatment for PepMV, several chemoand thermotherapeutic techniques were also evaluated by Cordoba-Selles et al. (1). However, authors in that report relied mainly on serological tests (enzyme-linked immunosorbent assay [ELISA]) and seedling grow-out assays to determine PepMV infectivity. In general, ELISA can detect a certain level of PepMV on tomato seed. However, the technique could not differentiate viable from nonviable virus particles on the treated seed. The objective of this study was to evaluate the efficacy of several commonly used chemo- and thermotherapeutic methods on PepMV in seed samples from a heavily PepMVcontaminated commercial tomato seed lot. Infectivity of PepMV remaining on the treated seed was evaluated in bioassay through mechanical inoculation on $N$. benthamiana plants, using symptom expression on the inoculated plants with confirmation test by ELISA

\section{MATERIALS AND METHODS}

Virus isolates and tomato seed sources. A commercial hybrid tomato seed lot (cv. Radja) imported from Chile in 2003 was an anonymous gift. Routine seed health assay with ELISA demonstrated that this seed lot contained PepMV and was free from two other potential seedborne viruses of tomato (Tomato mosaic virus [ToMV] and Tobacco mosaic virus [TMV]; data not shown). Previously, two genetic variants of PepMV (designated as Ch1 and Ch2) were isolated from seed in this seed lot and their genome sequences determined (8).

Chemotherapeutic seed treatments. Three commonly used chemicals for seed treatment, including sodium hypochlorite (commercial bleach), trisodium phosphate (TSP), and hydrochloric acid $(\mathrm{HCl})$, were evaluated. For each chemical, two concentrations were chosen based on previous experience in seed treatment for horticultural crops $(1,7)$. For each concentration of a chemical, three different time periods were selected depending on the chemical used (Table 1). Thus, there were six treatments for each chemical, plus one untreated seed sample as a control. For each treatment, 2,000 highly PepMVcontaminated tomato seed were used. After treatment, seed were rinsed thoroughly with running tap water to remove all chemical residues on the treated seed. One-half of the treated seed $(1,000)$ was used to determine remaining virus infectivity in bioassay through mechanical inoculation on $N$. benthamiana plants with processed seed extract as described below. The second half $(1,000$ treated seeds) was used to determine seed germination. For commercial bleach treatment, two working 
solutions $(0.5$ or $1.0 \%$ sodium hypochlorite) were used. Similarly, for TSP treatment, two working solutions (10 or 20\%) were applied. For $\mathrm{HCl}$ treatment, two solutions $(1.25$ or $1.50 \% \mathrm{HCl})$ were prepared from a commercial-grade $\mathrm{HCl}(37 \%)$. All seed treatment solutions were prepared in sterile distilled water with $0.1 \%$ Triton-X100 to improve chemical coverage on seed. Each treated seed sample was either processed immediately or air dried on a clean paper towel at room temperature until use in bioassay or seed germination.

Thermotherapeutic seed treatments. Two thermotherapeutic treatment methods (7), including hot-water soaking and dryheat baking, were evaluated. For hot-water soaking, two temperature regimes (50 and $55^{\circ} \mathrm{C}$ ) were used in three different time periods $(0.5,1$, and $2 \mathrm{~h})$ for a total of six treatments. For each treatment, seed samples with sufficient seed $(2,000$ per treatment) were soaked in two individual water baths (IsoTemp 210; Fisher Scientific, Pittsburgh) that were prewarmed to a designated temperature $\left(50\right.$ or $\left.55^{\circ} \mathrm{C}\right)$ for the predetermined length of time $(0.5,1$, or 2 h). Similarly, for dry-heat treatments, seed samples were treated at two temperature regimes $\left(72\right.$ or $\left.80^{\circ} \mathrm{C}\right)$ in three different time periods $(24,48$, and $72 \mathrm{~h})$ using a Yamato constant-temperature oven (DKN600; Yamato Scientific America, Inc., Orangeburg, NY). This oven is capable of air circulation to ensure even distribution of temperature in the oven. Experiments were designed to ensure that the number of seeds treated under each treatment conditions was sufficient for bioassay evaluation and for seed germination.

Bioassay with mechanical inoculation on $N$. benthamiana plants. The initial experiment was used to evaluate the comparative effectiveness of virus deactivation upon stated treatment conditions. It was conducted in four replicate subsamples for each treatment using bioassay through mechanical inoculation of processed seed extract on multiple (three to four) indicator plants to assess remaining virus infectivity. Bioassays were conducted using mechanical inoculation and observation of symptom expression on $N$. benthamiana plants. Seed extract in each replicate (250 seeds) was processed with a polytron PT10-35 homogenizer (Kinematica $\mathrm{GmbH}$, Lucerne, Switzerland) in 1:10 (wt/vol) prechilled $\left(4^{\circ} \mathrm{C}\right)$ phosphate-buffered saline (137 mM NaCl, $8 \mathrm{mM} \mathrm{Na} \mathrm{HPO}_{4}, 5 \mathrm{mM}$ $\mathrm{KH}_{2} \mathrm{PO}_{4}, 2.7 \mathrm{mM} \mathrm{KCl}$, and $7.9 \mathrm{mM}$ $\mathrm{Na}_{2} \mathrm{SO}_{3}$, pH 7.0). To prevent contamination between subsamples, the polytron probe was disinfected by triple rinses, first in water, followed by $70 \%$ ethanol, and then in water again before use for the next sample. The effectiveness of bioassay using polytron-processed tomato seed extract for inoculation and the triple-rinsing procedure to prevent potential cross contamination on a polytron probe after seed processing was assessed previously (9). In some cases, seed or leaf tissue samples were also processed in disposable plastic extraction bags using Homex-6 homogenizer (BioReba, Switzerland). Although plastic bags should reduce the chance of cross contamination during sample preparation, tomato seed tissue could be processed finer using a polytron than with a Homex-6. Nevertheless, in each experiment, healthy control seed samples were

Table 1. Comparative effectiveness of different chemo- and thermotherapeutic methods against Pepino mosaic virus infectivity and seed germination in tomato

\begin{tabular}{|c|c|c|c|c|c|}
\hline Treatment & $\begin{array}{c}\text { Concentration or } \\
\text { temperature }\end{array}$ & $\begin{array}{l}\text { Incubation } \\
\text { time }\end{array}$ & $\begin{array}{c}\text { Number of seeds } \\
\text { treated }\end{array}$ & $\begin{array}{c}\text { Sample infection rate } \\
(\%)^{\mathrm{a}}\end{array}$ & $\begin{array}{c}\text { Germination rate } \\
(\%)\end{array}$ \\
\hline \multirow{6}{*}{$\begin{array}{l}\text { Sodium hypochlorite } \\
\text { (commercial bleach) }\end{array}$} & \multirow{3}{*}{$0.5 \%$} & $10 \mathrm{~min}$ & $4 \times 250$ & $0 / 4(0)$ & 97.5 \\
\hline & & $15 \mathrm{~min}$ & $4 \times 250$ & $1 / 4(25)$ & 97.0 \\
\hline & & $30 \mathrm{~min}$ & $4 \times 250$ & $0 / 4(0)$ & 97.5 \\
\hline & \multirow[t]{3}{*}{$1.0 \%$} & $10 \mathrm{~min}$ & $4 \times 250$ & $4 / 4(100)$ & 96.5 \\
\hline & & $15 \mathrm{~min}$ & $4 \times 250$ & $0 / 4(0)$ & 98.5 \\
\hline & & $30 \mathrm{~min}$ & $4 \times 250$ & $0 / 4(0)$ & 94.5 \\
\hline \multirow[t]{6}{*}{ Trisodium phosphate (TSP) } & \multirow[t]{3}{*}{$10 \%$} & $0.5 \mathrm{~h}$ & $4 \times 250$ & $4 / 4(100)$ & 96.5 \\
\hline & & $1 \mathrm{~h}$ & $4 \times 250$ & $2 / 4(50)$ & 97.5 \\
\hline & & $2 \mathrm{~h}$ & $4 \times 250$ & $0 / 4(0)$ & 97.0 \\
\hline & \multirow{3}{*}{$20 \%$} & $0.5 \mathrm{~h}$ & $4 \times 250$ & $0 / 4(0)^{\mathrm{b}}$ & 98.5 \\
\hline & & $1 \mathrm{~h}$ & $4 \times 250$ & $0 / 4(0)^{\mathrm{b}}$ & 98.5 \\
\hline & & $2 \mathrm{~h}$ & $4 \times 250$ & $1 / 4(25)$ & 98.5 \\
\hline \multirow{6}{*}{ Hydrochloric acid $(\mathrm{HCl})$} & \multirow[t]{3}{*}{$1.5 \%$} & $0.5 \mathrm{~h}$ & $4 \times 250$ & $2 / 4(50)$ & 99.0 \\
\hline & & $1 \mathrm{~h}$ & $4 \times 250$ & $2 / 4(50)$ & 98.5 \\
\hline & & $2 \mathrm{~h}$ & $4 \times 250$ & $2 / 4(50)$ & 96.5 \\
\hline & \multirow[t]{3}{*}{$1.25 \%$} & $0.5 \mathrm{~h}$ & $4 \times 250$ & $0 / 4(0)^{b}$ & 97.0 \\
\hline & & $1 \mathrm{~h}$ & $4 \times 250$ & $4 / 4(100)$ & 98.0 \\
\hline & & $2 \mathrm{~h}$ & $4 \times 250$ & $2 / 4(50)$ & 98.5 \\
\hline \multirow[t]{6}{*}{ Hot water } & \multirow[t]{3}{*}{$50^{\circ} \mathrm{C}$} & $0.5 \mathrm{~h}$ & $4 \times 250$ & $4 / 4(100)$ & 97.5 \\
\hline & & $1 \mathrm{~h}$ & $4 \times 250$ & $1 / 4(25)$ & 98.5 \\
\hline & & $2 \mathrm{~h}$ & $4 \times 250$ & $0 / 4(0)$ & 94.5 \\
\hline & \multirow[t]{3}{*}{$55^{\circ} \mathrm{C}$} & $0.5 \mathrm{~h}$ & $4 \times 250$ & $1 / 4(25)$ & 96.0 \\
\hline & & $1 \mathrm{~h}$ & $4 \times 250$ & $0 / 4(0)$ & 89.5 \\
\hline & & $2 \mathrm{~h}$ & $4 \times 250$ & $0 / 4(0)$ & $52.0^{\mathrm{c}}$ \\
\hline \multirow[t]{6}{*}{ Dry heat } & \multirow[t]{3}{*}{$72^{\circ} \mathrm{C}$} & $24 \mathrm{~h}$ & $12 \times 250$ & $1 / 12(8.3)$ & 95.9 \\
\hline & & $48 \mathrm{~h}$ & $12 \times 250$ & $0 / 12(0)$ & 96.3 \\
\hline & & $72 \mathrm{~h}$ & $12 \times 250$ & $0 / 12(0)$ & 96.5 \\
\hline & \multirow[t]{3}{*}{$80^{\circ} \mathrm{C}$} & $24 \mathrm{~h}$ & $48 \times 250$ & $2 / 48(4.2)$ & 97.0 \\
\hline & & $48 \mathrm{~h}$ & $48 \times 250$ & $1 / 48(2.1)$ & 96.5 \\
\hline & & $72 \mathrm{~h}$ & $48 \times 250$ & $0 / 48(0)$ & 94.8 \\
\hline Nontreated seed & $\ldots$ & $\ldots$ & $4 \times 250$ & $4 / 4(100)$ & 97.0 \\
\hline
\end{tabular}

${ }^{a}$ Bioassays were conducted through mechanical inoculation of Nicotiana benthamiana plants with each replicate of seed extract (250 seeds/replicate) prepared in phosphate buffer. A positive infection on the inoculated plants was determined based on the symptom expression and serological confirmation (i.e., enzyme-linked immunosorbent assay). Only those treatments that resulted in no virus infection on the inoculated plants were considered complete deactivation. Thus, any inoculated plant resulting in a positive infection was considered an incomplete treatment. To simplify the presentation, data from all replications in the same treatment were combined.

${ }^{\mathrm{b}}$ Treatments with complete deactivation were likely due to the uneven distribution of PepMV-infested seed in a replicate or a variation in the inoculation, because a sample with longer treatment under that condition developed virus infection. Although precautionary steps were taken to minimize the chance of cross contamination, it could not be ruled out completely.

${ }^{\mathrm{c}}$ In statistical analysis, the hot-water soaking for $120 \mathrm{~min}$ was the only treatment resulting in a significant reduction in seed germination compared with the control based on the least significant difference test at $P \leq 0.05$. 
always processed first, followed by samples with higher stringency in treatment (with stronger concentration or higher temperature and longer hours), and finally the ones with lower stringency (with lesser concentration or lower temperature and shorter hours). To minimize any chance of contamination, positive control seed samples were always processed last in an experiment. The processed seed extract was soaked for $30 \mathrm{~min}$ at room temperature with occasional mixing to facilitate release of virus particles into the buffer. To ensure a thorough evaluation of any remaining virus infectivity on a treated seed sample, bioassay was performed on multiple indicator plants. In general, for each replicate, three to four $N$. benthamiana seedlings at the three- to five-leaf stage were inoculated. For mechanical inoculation, processed seed extract was gently rubbed with a cotton swab onto lightly Carborundumdusted leaves (320-mesh grit powder; Fisher Scientific) of assay plants. After rinsing to remove excess inoculum and Carborundum, the inoculated plants were initially placed under shade for a few hours to minimize direct sunlight damage to the inoculated leaves and then maintained in a greenhouse ( 20 to $30^{\circ} \mathrm{C}, 12$ - to 14 -h natural lighting period) for symptom expression. To ensure success in inoculation, positive controls of a nontreated PepMVinfested tomato seed extract and a PepMVinfected tomato leaf tissue were also included. To prevent any accidental cross contamination in inoculation, gloves were worn during inoculation and changed between subsamples. A positive virus infection was evident with symptom expression (yellow mosaic and leaf deformation) on the inoculated $N$. benthamiana plants. Final symptom evaluation was performed 4 weeks post inoculation. A subsample was considered positive if any one of its inoculated plants was found to be infected by PepMV through symptom expression and confirmation by ELISA. Once the dry-heat treatments were shown to be the most promising ones, additional replicate experiments were performed in 3 experiments for treatments at $72^{\circ} \mathrm{C}$ and as many as 12 separate experiments for treatments at $80^{\circ} \mathrm{C}$ to determine the consistency and the effectiveness of such treatments. Virus infectivity remaining on the treated seed samples was observed only in a small fraction of total samples tested. To simplify the presentation, data from all replications in the same treatment were combined in the report (Table 1). A seed treatment was considered good only when its treated seed resulted in complete deactivation of virus infectivity in all repetitive experiments in bioassay and it had no adverse effect on seed germination.

Serological analysis. The antibody to PepMV was obtained from Agdia (Elkhart, IN) and double-antibody sandwich (DAS)ELISA was conducted following the manu- facturer's instructions. The absorbance value was read $1 \mathrm{~h}$ after substrate hydrolysis at an optical density of $405 \mathrm{~nm}$ in a SpectraMax Plus 384 (Molecular Devices, Sunnyvale, CA). A sample was considered positive if its absorbance value was more than twice that of the mean healthy seed control.

Seed germination. Seed germination was conducted following the standard method for tomato seed using the Association of Official Seed Analysts rules (http://www.aosaseed.com). For each treatment, four replicates of 100 seeds (a total of 400 seeds) were placed between moist filter papers and incubated in a growth chamber $\left(25^{\circ} \mathrm{C}, 12-\mathrm{h}\right.$ photoperiod). The rate of seed germination was first counted at 7 days with a final count at 14 days. Once the rate of seed germination was determined, data from different treatments were subjected to the analysis of variance and means were separated using the least significant difference test at $P \leq$ 0.05 .

\section{RESULTS}

Efficacy of chemotherapeutic treatments. The efficacy of seed-disinfection treatments was evaluated through bioassay on $N$. benthamiana plants to determine whether viable PepMV remained on the treated seed. In treatments with bleach solutions, infectious virus was still detected in seed samples treated in $0.5 \%$ sodium hypochlorite for $15 \mathrm{~min}$. However, longer soaking time (30 $\mathrm{min}$ ) in both concentrations $(0.5$ and $1 \%)$ achieved a complete deactivation of virus infectivity on the treated seed with no adverse effect on germination (Table 1). For TSP treatments, at a lower concentration (10\%), the virus infectivity was reduced as the soaking time increased (Table 1). Virus infectivity remaining on the treated seed in samples receiving $1 \mathrm{~h}$ of treatment was only $50 \%$. A complete deactivation of PepMV infectivity was achieved in seed samples with $2 \mathrm{~h}$ of treatment. In seed samples treated with TSP, although virus titers on the treated seed as measured by ELISA were dramatically reduced (from a mean absorbance value of $1.271 \pm 0.09$ in the nontreated samples to $0.182 \pm 0.046$ in the TSPtreated ones) (data not shown), infectious virus was detected on the treated seed upon inoculation on $N$. benthamiana plants (Table 1). Although the higher concentration of TSP $(20 \%)$ appeared to be more effective with shorter time in treatment (30 min or $1 \mathrm{~h}$ ), virus infectivity was still detected in one of the four replicates that received longer treatment $(2 \mathrm{~h}$; Table 1$)$. Whereas the commercial bleach and TSP treatments showed some promise, results from the $\mathrm{HCl}$ treatments were variable (Table 1). PepMV remained highly infectious in more than half of the HCl-treated subsamples even after $2 \mathrm{~h}$ of soaking time with both concentrations (1.25 or $1.5 \%)$.
Even though the effects on PepMV infectivity in the treated seed varied greatly among different chemicals, the rate of seed germination was not affected significantly by the described treatment conditions (Table 1).

Efficacy of thermotherapeutic treatments. Two thermo-treatment methods, hot-water soaking and dry-heat baking, were evaluated for their efficacy in deactivating PepMV infectivity on treated tomato seed. The results showed that virus infectivity was gradually reduced by hotwater treatments as the soaking time increased. Virus infectivity remained the same as untreated controls in all the replicates of seed treated at $50^{\circ} \mathrm{C}$ for $0.5 \mathrm{~h}$. The levels of virus infectivity were reduced to $25 \%$ in seed treated for $1 \mathrm{~h}$ and nondetectable in seed samples in $2 \mathrm{~h}$ treatment (Table 1). In comparison, when seed were treated at a higher temperature $\left(55^{\circ} \mathrm{C}\right)$, only $25 \%$ of treated seed samples contained infectious viruses after $0.5 \mathrm{~h}$ of treatment and virus infectivity was completely deactivated in samples received longer treatments ( 1 or $2 \mathrm{~h}$; Table 1 ). In germination tests, even though seed treatment at lower temperature $\left(50^{\circ} \mathrm{C}\right)$ did not greatly affect seed germination, germination rate was significantly impacted in seed that received prolonged treatment (i.e., $2 \mathrm{~h}$ ) at a higher temperature $\left(55^{\circ} \mathrm{C}\right.$; Table 1$)$. Due to this potential adverse effect on seed germination by hot-water treatment, the emphasis on thermotherapeutic treatment subsequently focused on dry-heat baking. At both 72 and $80^{\circ} \mathrm{C}$, virus infectivity was significantly reduced compared with untreated controls on seed with $24-$ and 48-h treatments. Total deactivation of the virus infectivity was made possible when seed samples received a longer treatment of 72 $\mathrm{h}$ (Table 1). To determine the consistency of virus deactivation by dry-heat baking, more treated seed in multiple replications were evaluated. For example, in a $72^{\circ} \mathrm{C}$ treatment at 24,48 , and $72 \mathrm{~h}, 12$ replicates were analyzed. Results showed that 1 of 12 replicates in the 24-h treatment generated positive PepMV infection upon inoculation (Table 1). However, the virus infectivity was totally destroyed in all 12 replicates that received treatments at $72^{\circ} \mathrm{C}$ for a longer period of time (e.g., 48 or $72 \mathrm{~h}$ ). For dry-heat treatment at $80^{\circ} \mathrm{C}, 48$ replicates (with 250 seeds/replicate for a total of 12,000 seeds) were evaluated at each time point $(24,48$, or $72 \mathrm{~h})$. Results showed that 2 of 48 replicates at $24 \mathrm{~h}$ and 1 of 48 replicates at $48 \mathrm{~h}$ showed PepMV infection on the inoculated $N$. benthamiana plants. In germination tests, although the rate of emergence in the first count at 7 days post germination was delayed for approximately 1 day in the dry-heat-treated seed samples compared with the untreated control ones, the germination rate was not significantly affected in the final count at 14 days (Table 1). Thus, seed that were 
treated at 72 or $80^{\circ} \mathrm{C}$ for $72 \mathrm{~h}$ achieved a desirable total deactivation of virus infectivity, which also resulted in a negligible effect on seed germination.

\section{DISCUSSION}

Seed treatment methods have largely been developed by major seed companies for a number of important seedborne pathogens in vegetables $(7,11)$. Usually, these seed treatment methods are proprietary and may not be available to the general public or small seed companies. It was recently determined that PepMV is a seedborne but not seed-transmitted virus in tomato, and the ease of mechanical transmission of PepMV from contaminated tomato seed to seedlings was likely responsible for initiating virus infection (9). In the present study, three commonly used chemicals (commercial bleach, TSP, and $\mathrm{HCl}$ ) and two thermotherapeutic treatments (hot water and dry heat) were evaluated for their effectiveness in eliminating virus infectivity in seed samples taken from a heavily PepMV-contaminated commercial hybrid tomato seed lot. Following each treatment, the remaining virus infectivity on the treated seed sample was assessed through bioassay by mechanical inoculation of the processed seed extract on $N$. benthamiana. Although a similar study on seed treatment for PepMV on tomato seed was reported (1), authors in that study did not use a bioassay to assess how much infectious virus remained on the treated seed. Instead, they relied mainly on ELISA to detect PepMV on the treated seed samples. Using ELISA to test for PepMV on the treated whole seed may have overestimated the level of virus infectivity because ELISA cannot distinguish viable from nonviable viruses on the treated seed. This overestimation could result in an unnecessary rejection of a valuable seed lot. A false-positive ELISA reading may also be undesirable for certification of virus-free seed. For a seedborne but not seed-transmitted virus like PepMV (9), grow-out of seedlings through a natural germination process will likely not result in virus infection even from PepMVcontaminated seed. Because PepMV is transmitted easily by mechanical means, bioassay is a better solution in determining virus infectivity remaining on the treated seed. Any infectious virus particles remaining on the treated seed could potentially serve as an initial virus inoculum. This ease in mechanical transmission of PepMV from contaminated seed to seedlings could potentially result in the serious consequence of virus introduction to a new area through contaminated hands or tools during greenhouse seedling preparation or tomato production. Thus, the goal for an effective seed treatment is to achieve a total deactivation of virus infectivity in the treated seed as determined through bioassay on $N$. benthamiana plants without loss of seed germination.

The surface-locating nature of PepMV on tomato seed (9) suggests that PepMV can be inactivated with chemo- or thermotherapeutic seed treatments. The conventional seed treatments, including TSP and bleach solution that are effective against Tobamovirus spp. (e.g., TMV and ToMV; 7), also resulted in significantly reduced levels of infectious PepMV in treated seed samples. The commercial bleach treatment was the best among the three chemicals. Results from the TSP treatments varied. The present study demonstrated that, even though the TSP treatment significantly reduced virus infectivity, it did not completely inactivate the virus. It was also important to thoroughly mix or submerge seed in the chemical solution during treatment. Addition of Triton-X-100 to solutions also improved chemical coverage on seed.

In conclusion, the effective chemo- and thermotherapeutic treatment methods against PepMV described here should provide seed companies and smaller growers another tool to manage this everincreasing problem facing the greenhouse tomato industry. Chemo- or thermotherapeutic methods can reduce or even eliminate infectious virus particles on PepMVcontaminated commercial tomato seed. These different mechanisms of deactivating virus infectivity through chemo- and thermotherapeutic methods might be able to be combined to achieve even greater success in seed treatment.

\section{ACKNOWLEDGMENTS}

I thank A. Gilliard and E. Walters for technical assistance in conducting the experiments and A. Simmons and H. Harrison for critical reading of the manuscript and assistance in statistical analysis.

\section{LITERATURE CITED}

1. Cordoba-Selles, M. C., Garcia-Randez, A., Alfaro-Fernandez, A., and Jorda-Gutierrez, C. 2007. Seed transmission of Pepino mosaic virus and efficacy of tomato seed disinfection treatments. Plant Dis. 91:1250-1254.

2. Cotillon, A. C., Girard, M., and Ducouret, S. 2002. Complete nucleotide sequence of the genomic RNA of a French isolate of Pepino mosaic virus (PepMV). Arch. Virol. 147:22312238.

3. French, C. J., Bouthillier, M., Bernardy, M., Ferguson, G., M., Johnson, R. C., Masters, C., Godkin, S., and Mumford, R. 2001. First report of Pepino mosaic virus in Canada and the United States. Plant Dis. 85:1121.

4. Hanssen, I. M., Mumford, R., Blystad, D.-R., Cortez, I., Hasiow-Jaroszewska, B., Hristova, D., Pagan, I., Pereira, A.-M., Peters, J., Pospieszny, H., Ravnikar, M., Stijger, I., Tomassoli, L., Varveri, C., Van der Vlugt, R., and Nielsen, S. L. 2009. Seed transmission of Pepino mosaic virus in tomato. Eur. J. Plant Pathol. (pub- lished online DOI 10.1007/s10658-0099528-x).

5. Hanssen, I. M., Paeleman, A., Wittemans, L., Goen, K., Lievens, B., Bragard, C., Vanachter, A. C. R. C., and Thomma, B. P. H. 2008. Genetic characterization of Pepino mosaic virus isolates from Belgian greenhouse tomatoes reveals genetic recombination. Eur. J. Plant Pathol. 121:131-146.

6. Jorda, C., Lazaro-Perez, A., MartinezCulebras, P. V., Abad, P., Lacasa, A., and Guerrero, M. M. 2001. First report of Pepino mosaic virus on tomato in Spain. Plant Dis. 85:1292.

7. Lee, J. M. 2004. Advances in seed treatments for horticultural crops. Chronica Hortic. 44(2):11-20. (also available online: http://www.ishs.org/chronica/)

8. Ling, K. S. 2007. Molecular characterization of two Pepino mosaic virus variants from imported tomato seed reveals high levels of sequence identity between Chilean and US isolates. Virus Genes 34:1-8.

9. Ling, K. S. 2008. Pepino mosaic virus on tomato seed: virus location and mechanical transmission. Plant Dis. 92:1701-1705.

10. Ling, K. S., Wintermentel, W. M., and Bledsoe, M. 2008. Genetic composition of Pepino mosaic virus population in North American greenhouse tomatoes. Plant Dis. 92:1683-1688.

11. Lovic, B. R., and Hopkins, D. L. 2003. Production steps to reduce seed contamination by pathogens of cucurbits. HortTechnology 13:50-54.

12. Maroon-Lango, C. J., Guaragna, M. A., Jordan, R. L., Hammond, J., Bandla, M., and Marquardt, S. K. 2005. Two unique US isolates of Pepino mosaic virus from a limited source of pooled tomato tissue are distinct from a third (European-like) US isolate. Arch. Virol. 150:1187-1201.

13. Mumford, R. A., and Metcalfe, E. J. 2001. The partial sequencing of the genomic RNA of a UK isolate of Pepino mosaic virus and the comparison of the coat protein sequence with other isolates from Europe and Peru. Arch. Virol. 146:2455-2460.

14. Pagan, I., Cordoba-Selles, M. C., MartinezPriego, L., Fraile, A., Malpica, J. M., Jorda, C., and Garcia-Arenal, F. 2006. Genetic structure of the population of Pepino mosaic virus infecting tomato crops in Spain. Phytopathology 96:274-279

15. Pospieszny, H., and Borodynko, N. 2006. New Polish isolate of Pepino mosaic virus highly distinct from European tomato, Peruvian, and US2 strains. Plant Dis. 90:1106.

16. Roggero, P., Masenga, V., Lenzi, R, Coghe, F. Ena, S., and Winter, S. 2001. First report of Pepino mosaic virus in tomato in Italy. Plant Pathol. 50:798.

17. Salomone, A., and Roggero, P. 2002. Host range, seed transmission and detection by ELISA and lateral flow of an Italian isolate of Pepino mosaic virus. J. Plant Pathol. 84:65-68.

18. Soler, S., Prohens, J., Diez, M. J., and Nuez F 2002. Natural occurrence of Pepino mosaic virus in Lycopersicon species in Central and Southern Peru. J. Phytopathol. 150:49-53.

19. van der Vlugt, R. A. A., Stijger, C. C. M. M., Verhoeven, J. Th. J., and Lesemann, D. E. 2000. First report of Pepino mosaic virus on tomato. Plant Dis. 84:103.

20. Zhang, Y., Shen, Z. J., Zhong, J., Lu, X. L., Cheng, G., and Li, R. D. 2003. Preliminary characterization of Pepino mosaic virus Shanghai isolate (PepMV-Sh) and its detection with ELISA. Acta Agric. Shanghai 19:90-92. 